PART II. PHYSICAL ACTIVITY OF SOCIAL AND PROFESSIONAL GROUPS

DZIAŁ II. AKTYWNOŚĆ FIZYCZNA GRUP SPOŁECZNYCH I ZAWODOWYCH

\title{
PHYSICAL ACTIVITY OF ELITE FOOTBALL PLAYERS USING DIFFERENT REGIMES OF ENERGY METABOLISM
}

\section{AKTYWNOŚĆ FIZYCZNA ELITARNYCH PIŁKARZY NOŻNYCH W RÓŻNYCH REŻIMACH METABOLIZMU ENERGETYCZNEGO}

\author{
Volodymyr Lyzohub $^{1(\mathrm{~A}, \mathrm{D}, \mathrm{E}, \mathrm{F})}$, Tetiana Kozhemiako ${ }^{1(\mathrm{~B}, \mathrm{D}, \mathrm{F})}$, Sergii Khomenko ${ }^{1(\mathrm{C}, \mathrm{D}, \mathrm{E})}$, \\ Vitalii Pustovalov $^{2(B, C, F)}$, Vitalii Shpaniuk ${ }^{2(B, E, F)}$
}

${ }^{1}$ Department of Anatomy, Physiology and Physical Rehabilitation,

Bohdan Khmelnitsky National University, Cherkassy, Ukraine

${ }^{2}$ Department of Sports Games, Bohdan Khmelnitsky National University, Cherkassy, Ukraine

Authors' contribution Wkład autorów: A. Study design/planning zaplanowanie badań B. Data collection/entry zebranie danych C. Data analysis/statistics dane - analiza i statystyki D. Data interpretation interpretacja danych E. Preparation of manuscript przygotowanie artykułu F. Literature analysis/search wyszukiwanie i analiza literatury G. Funds collection zebranie funduszy

\section{Summary}

Background. The physical activity of 29 football players using either aerobic or anaerobic energy regimes was tested during official games and in the laboratory.

Material and methods. Under conditions of gradually increasing power on a treadmill, maximal running speed $(\mathrm{V}, \mathrm{km} / \mathrm{h})$, oxygen consumption $\left(\mathrm{VO}_{2}, \mathrm{~mL} / \mathrm{min} / \mathrm{kg}\right)$, heart rate $(\mathrm{HR}$, beats/min), and anaerobic metabolism threshold (AT $\mathrm{mL} / \mathrm{min} / \mathrm{kg}$ ) were determined, and blood lactate (BLact, $\mathrm{mmol} / \mathrm{L}$ ) was measured.

Results. The correlation between the total length of distance run during the game and treadmill running speed for the outcome measures were as follows: anaerobic metabolism threshold, $r=0.54(p=0.032)$, BLact, $r=0.37(p=0.034), V_{2} \max , r=0.41(p=0.027)$, and HR, $r=0.36(p=0.047)$. We found aerobic mechanisms were dominant in ensuring the game activity of football players. Specifically, aerobic mechanisms contribute roughly $32.4-43.8 \%$ to playing activity, while aerobic-anaerobic energy supply mechanisms provide for only $17 \%$. Lactic and alactic mechanisms provide for $5.6 \%$ and $1.6 \%$, respectively.

Conclusions. The results provide valuable information on the relationship between football play activity and aerobic and anaerobic energy supply mechanisms. Enhancing the functionality of the anaerobic lactic-alactic energy system can lead to growth and improvements in physical performance in football players.

Keywords: telemetry, oxygen consumption, energy metabolism, lactate

\section{Streszczenie}

Wprowadzenie. Dwudziestu dziewięciu piłkarzy nożnych zostało przebadanych pod kątem aktywności fizycznej w aerobowych i anaerobowych reżimach energetycznych podczas oficjalnych meczów oraz w laboratorium.

Materiał i metody. W warunkach stopniowo wzrastającej mocy na bieżni ruchomej określano maksymalną prędkość biegu $(\mathrm{V}, \mathrm{km} / \mathrm{h})$, pobór tlenu $\left(\mathrm{VO}_{2}, \mathrm{~mL} / \mathrm{min} / \mathrm{kg}\right)$, tętno (HR, uderzeń $/ \mathrm{min}$ ), próg przemian beztlenowych (AT $\mathrm{mL} / \mathrm{min} / \mathrm{kg}$ ) oraz mierzono stężenie mleczanu we krwi (BLact, mmol/L).

Wyniki. Korelacja pomiędzy długością dystansu podczas gry a prędkością biegu na bieżni na poziomie progu beztlenowego wyniosła $r=0,54(p=0,032)$, dla BLact $r=0,37(p=0,034)$, a VO ${ }_{2} \max r=0,41(p=0,027)$ i HR r=0,36 ( $\left.p=0,047\right)$. Stwierdzono, że mechanizmy aerobowe sa dominujące w zapewnieniu aktywności meczowej piłkarzy nożnych. Ich udział w aktywności ruchowej wynosi 32,4-43,8\%, podczas gdy mechanizmy tlenowo-anaerobowe dostarczają $17 \%$ energii, a mechanizmy z udziałem mleczanu lub anaerobowe bezmleczanowe odpowiednio $5,6 \%$ i $1,6 \%$.

Wnioski. Uzyskane wyniki dostarczają cennych informacji na temat zależności pomiędzy aktywnością sportową w piłce nożnej a tlenowymi i beztlenowymi mechanizmami zaopatrzenia w energię. Wykazano, że zwiększenie funkcjonalności beztlenowych mechanizmów energii z udziałem mleczanu lub bezmleczanowych może prowadzić do wzrostu i poprawy wydolności fizycznej piłkarzy nożnych.
Tables: 2
Figures: 1

References: 30

Submitted: 2021 Jun 1

Accepted: 2021 Jul 9

Słowa kluczowe: telemetria, zużycie tlenu, metabolizm energetyczny, mleczan

Lyzohub V, Kozhemiako T, Khomenko S, Pustovalov V, Shpaniuk V. Physical activity of elite football players using different regimes of energy metabolism. Health Prob Civil. 2021; 15(3): 202-210. https://doi.org/10.5114/hpc.2021.107781

Address for correspondence / Adres korespondencyjny: Volodymyr Lyzohub, Department of Anatomy, Physiology and Physical Rehabilitation, Bohdan Khmelnitsky National University, 81 Shevchenko Boulevard, 18031 Cherkasy,Ukraine, e-mail: v_lizogub@ukr.net, phone: +380 (0472) 372142

ORCID: Volodymyr Lyzohub https://orcid.org/0000-0002-3001-138X, Tetiana Kozhemiako https://orcid.org/0000-0003-4752-4197,

Serhii Khomenko https://orcid.org/0000-0003-0918-8735, Vitalii Pustovalov https://orcid.org/0000-0002-8625-6175,

Vitalii Shpaniuk https://orcid.org/0000-0002-1147-8603

Copyright: (C) Pope John Paul II State School of Higher Education in Biała Podlaska, Volodymyr Lyzohub, Tetiana Kozhemiako, Sergii Khomenko, Vitalii Pustovalov, Vitalii Shpaniuk. This is an Open Access journal, all articles are distributed under the terms of the Creative Commons Attribution-NonCommercial-ShareAlike 4.0 International (CC BY-NC-SA 4.0) License (http://creativecommons.org/licenses/by-nc-sa/4.0/), allowing third parties to copy and redistribute the material in any medium or format and to remix, transform, and build upon the material, provided the original work is properly cited and states its license. 


\section{Introduction}

In the practice of sports medicine and physiology, research is primarily focused on finding ways to manage or optimize training protocols based on the objectification of knowledge about health and individual functionality of different systems [1-3], along with physical performance and activity of athletes [4-7]. Physical activity of football players depends on the morpho-functional characteristics of the body, strength, endurance, and muscle coordination [8,9], as well as the power, capacity, and efficiency of an individual's energy supply mechanisms $[7,10]$. The level of game activity of football players is influenced by the nature of technical and tactical tasks they perform during the game, their sports qualifications, psychological and functional training $[4,11,12]$. These components of physical activity are important for achieving high results in football.

During the course of a match, football players typically undergo considerable amounts of physical activity and movement, and continuously must change direction of their motor actions depending on the game situation. Throughout this physical activity, the metabolic state also acquires rapid changes in nature and intensity $[5,13,14]$. High levels of physical activity in football players are determined by the power, capacity, and efficiency of muscle adenosine triphosphate, along with aerobic, aerobic-anaerobic, and lactic and alactic energy sources $[10,11,14]$. An objective assessment of the state of physical activity of football players while playing in different modes of energy metabolism is an important task of sports medicine. Therefore, it is necessary to know how playing activity is connected with energy metabolism in football players.

Numerous studies on the playing activity of football players using digital media recording methods found significant differences. It was also established the average football player covers a distance of 8-12 km per game $[4,15,16]$. Moreover, midfielders and flanking players typically run the greatest distance throughout a match, while attackers and central defenders cover a slightly shorter distance $[5,11,17]$. The average distance per game for English club players is 11,472 m [18]. For Belgian teams, running activity during a football game was measured at 9,202 $\mathrm{m}$ for defenders, 10,719 $\mathrm{m}$ for midfielders, and 9,820 $\mathrm{m}$ for forwards. These results were different for football players from Italian teams, which showed that forwards run approximately 10,480 m, while midfielders ran $11,000 \mathrm{~m}$, and defenders about 9,740 $\mathrm{m}$ [19]. These results revealed significant differences between the specific difference travelled throughout a game for football players. In order to clarify the aforementioned results relating to the distance traveled by players during a football match, research should also be conducted using modern multi-channel GPSports-systems. With the advent of "Catapult", "EVO", "Polar", "Meta Max Cortex", and other telemetry systems, it became possible to analyze the features of the physical activity of football players throughout a game in more detail [20,21]. Despite these technological advancements, there is very little information in the literature on the distance travelled per game due to the peculiarities of energy metabolism.

Researchers believe that the physical activity of players throughout a game can be determined and evaluated by the average speed and volume of running activity [22-24]. Others emphasize the need to test this physical activity only in conditions close to competitive activities [20,22]. Laboratory testing of physical performance to mimic competitive matches for sports is irrational and not informative enough $[3,23]$. Thus, there is a need to determine suitable diagnostic possibilities of the physical activity of football players with the energy characteristics of anaerobic and aerobic support in laboratory studies [7,25].

Here, we assume physical activity throughout a game and physical performance of football players may be stipulated by differences in energy metabolism. Therefore, we tried to analyze the characteristics of general and special physical activity of football players, taking into account the different modes of energy metabolism. These modes were obtained during calendar games and the results determined in the laboratory.

The purpose of this study was to identify novel characteristics related to the physical activity of elite football players, specifically the relationship between differences in playing activity and various modes of energy metabolism.

\section{Material and methods}

29 football players took part in the experiment. The studies were approved by the Biomedical Ethics Commission, and the subjects were acquainted with the purpose of the study and agreed. The research was conducted in a laboratory and during competitive match conditions.

During the calendar games in the Ukrainian football championship of the 2019-2020 season, general physical performance was studied in the laboratory, and special physical performance was studied in the field conditions.

A single study regimen was followed by all subjects. Along with a comprehensive assessment of maximum aerobic and anaerobic capacity, critical power corresponding to the maximum oxygen consumption and the threshold of anaerobic metabolism was determined. 
The following anthropometric indicators of football players were determined: age, height (m), weight (kg), body mass index $\left(\mathrm{BMI}, \mathrm{kg} / \mathrm{m}^{2}\right)$, heart rate $(\mathrm{HR}$, beats $/ \mathrm{min})$, blood pressure (BP, $\mathrm{mmHg}$ ), blood lactate (BLact, $\mathrm{mmol} / \mathrm{L})$, the rate of oxygen consumption $\left(\mathrm{VO}_{2}, \mathrm{~mL} / \mathrm{kg} / \mathrm{min}\right)[26,27]$.

The next stage of the study was a test with a step-by-step increase in running speed on a "Schiller AG" treadmill (Switzerland). This work consisted of a warm-up and main part. The warm-up was performed for 5 minutes at a speed of $5 \mathrm{~km} / \mathrm{h}$, along with a track inclination at an angle of $2 \%$. A study by Volkov [13] found that aerobic processes at each stage of a given capacity unfolded after 45-60 s, and that the rapid phase of growth in oxygen uptake ends. Therefore, at each power stage, the duration of the load was one minute. The initial load was set at a running speed of $7 \mathrm{~km} / \mathrm{h}$, and the track angle was $25 \%$. The intensity of the run increased every minute in the following sequence: 10,13,16,19, 22 and $25 \mathrm{~km} / \mathrm{h}$, respectively. Speed thresholds were set in accordance with the recommendations of activity in the match, which corresponded to: walking - 0.7-7.1 $\mathrm{km} / \mathrm{h}$, jogging 7.2-14.3 km/h, aerobic running - 14.4-19.7 km/h, high-speed running - 19.8-25.1 km/h, and sprinting - >25.1 $\mathrm{km} / \mathrm{h}[5,11,15]$. The total time of the study did not exceed 10 minutes. At each stage of work on a treadmill, an ergospirometer was used (Metalyser 3B-R2, Cortex, Germany) to determine oxygen uptake indicators ( $\mathrm{VO}_{2}, \mathrm{ml} /$ $\mathrm{min} / \mathrm{kg}$ ). The rate of oxygen uptake was averaged over $30 \mathrm{~s}$ and the $\mathrm{VO}_{2} \mathrm{max}$, aerobic and anaerobic performance was determined $[13,27]$.

HR was recorded at rest and during an ergospirometric test using a HR monitor (Polar m400 HR, Polar Oy, Finland). The mean and maximum HR for each subject [22] was measured. The determination of lactate in the blood (BLact, mmol/L) was performed at rest and during each stage of loading using a ABL800 microanalyzer (Radiometr, Denmark). Anaerobic Threshold (AT), or the threshold above which metabolic acidosis develops, was determined according to the indicators of $\mathrm{BLact} \mathrm{VO}_{2}$, and $\mathrm{HR}$. The beginning of metabolic acidosis was considered to be an increase in lactate in the blood of more than $4.4 \mathrm{mmol} / \mathrm{L}[14,28]$.

The studies of the physical activity of football players in the field were conducted using the GPSports EVO telemetry system and the Polar telepulsemeter during calendar games in the national football championship. Special physical performance was determined by the overall distance $(\mathrm{S}, \mathrm{m})$, which players ran per game, and the average and maximum HR in aerobic, aerobic-anaerobic, lactic, and alactic modes of energy supply. GPSports EVO software included indicators: $\mathrm{V}$ run, $\mathrm{VO}_{2} \max , \mathrm{HR}$, and BLact, which were obtained at the level of AT in the study and set lactic, alactic, aerobic-anaerobic, aerobic, and restorative modes of energy metabolism [11,24].

Statistical analysis was performed with StatSoft STATISTICA 10.0 programs. The data on distribution normality were checked using the Shapiro-Wilk method. The data falling under the law of normal distribution are presented as mean values and arithmetic mean error $(\mathrm{M} \pm \mathrm{m})$; and the median $(\mathrm{Me})$, upper and lower quartiles (Me [Q25\%; Q75\%]) were determined for nonparametric results. Correlation analysis for groups falling under the normal distribution was performed using the Pearson correlation coefficient, and those that had a data distribution different from the normal one were analyzed using the Spearman correlation coefficient. The level of statistical significance was taken as $\mathrm{P}<0.05$ [29].

\section{Results}

In the laboratory, $\mathrm{V}$ run, $\mathrm{VO}_{2}$ max, $\mathrm{HR}$, BLact, and $\mathrm{AT}$ were determined with the help of a treadmill. In the field conditions, physical activity was studied during the game using the GPSports system; the length of distance the players ran per game, running speed, average and maximum HR were recorded; aerobic, aerobic-anaerobic, lactic, and alactic mechanisms of energy supply were determined.

\section{Physical activity of football players in laboratory conditions}

The average running speed (V) of football players was $17.6[10.8 ; 21.7] \mathrm{km} / \mathrm{h}$, and the rate of oxygen uptake $\left(\mathrm{VO}_{2} \max \right)$ was $59.3[56.3 ; 72.6] \mathrm{ml} / \mathrm{min} / \mathrm{kg}$. The maximum HR was $183.3[167.3 ; 195.4]$ beats $/ \mathrm{min}$, and BLact levels were 10.9 [8.2; 12.3] mmol/L (Table 1 ). 
Table 1. Indicators of physical activity and cardiorespiratory system of football players under step-increasing load on the treadmill $(\mathrm{n}=29)$

\begin{tabular}{|c|c|c|c|c|c|c|c|}
\hline \multicolumn{8}{|c|}{ Investigated indicators } \\
\hline $\mathrm{V},(\mathrm{km} / \mathrm{h})$ & 7 & 10 & 13 & 16 & 19 & 22 & 25 \\
\hline HR, beats $/ \mathrm{min}^{-1}$ & $\begin{array}{c}102.9 \\
{[96 ; 128]}\end{array}$ & $\begin{array}{c}128.0 \\
{[117 ; 137]}\end{array}$ & $\begin{array}{c}134.7 \\
{[121 ; 147]}\end{array}$ & $\begin{array}{c}145.3 \\
{[134 ; 153]}\end{array}$ & $\begin{array}{c}177.3 \\
{[159 ; 183]}\end{array}$ & $\begin{array}{c}174.4 \\
{[167 ; 187]}\end{array}$ & $\begin{array}{c}175.2 \\
{[169 ; 193]}\end{array}$ \\
\hline $\begin{array}{c}\mathrm{VO}_{2} \max \\
\mathrm{ml} / \mathrm{min} / \mathbf{k g}^{-1}\end{array}$ & $\begin{array}{c}43.0 \\
{[39 ; 48]}\end{array}$ & $\begin{array}{c}45.0 \\
{[37 ; 53]}\end{array}$ & $\begin{array}{c}50.3 \\
{[41 ; 57]}\end{array}$ & $\begin{array}{c}54.3 \\
{[42 ; 62]}\end{array}$ & $\begin{array}{c}58.8 \\
{[53 ; 67]}\end{array}$ & $\begin{array}{c}59.4 \\
{[50 ; 72]}\end{array}$ & $\begin{array}{c}59.7 \\
{[52 ; 69]}\end{array}$ \\
\hline $\begin{array}{c}\text { HLact. } \\
\left(\mathrm{mmol} / \mathrm{L}^{-1}\right)\end{array}$ & $\begin{array}{c}1.9 \\
{[1.5 ; 2.4]}\end{array}$ & $\begin{array}{c}2.3 \\
{[2.3 ; 3.3]}\end{array}$ & $\begin{array}{c}2.6 \\
{[2.2 ; 5.3]}\end{array}$ & $\begin{array}{c}3.7 \\
{[3.2 ; 5.3]}\end{array}$ & $\begin{array}{c}4.5 \\
{[3.8 ; 6.3]}\end{array}$ & $\begin{array}{c}6.7 \\
{[4.6 ; 7.8]}\end{array}$ & $\begin{array}{c}10.9 \\
{[8.2 ; 12.3]}\end{array}$ \\
\hline
\end{tabular}

The results show the maximum running speed of football players on a treadmill was $25 \mathrm{~km} / \mathrm{h}$. The guaranteed power reached by $100 \%$ of the players was $16 \mathrm{~km} / \mathrm{h}$, while a load capacity of 19 and $22 \mathrm{~km} / \mathrm{h}$ could be performed by only $84 \%$ and $53 \%$ of the players, respectively. The maximum values of physical performance, $25 \mathrm{~km} / \mathrm{h}$, was reached by only $6 \%$ of players. Thus, a physical performance limit, which is performed by most footballers in terms of treadmill speed, is $16 \mathrm{~km} / \mathrm{h}$, and this value can be considered as a normative test.

Analysis of the results revealed a relationship between $\mathrm{HR}, \mathrm{VO}_{2} \max$, and $\mathrm{V}$ at loads of $7,10,13$, and $16 \mathrm{~km} / \mathrm{h}$. The results demonstrate the high level of physical activity on a treadmill was characterized by higher values of $\mathrm{HR}$ and $\mathrm{VO}_{2} \max$. A gradual increase in running speed on a treadmill led to an increase in the performance of the oxygen transport system. Further increase in running speed on a treadmill to 19,22 and $25 \mathrm{~km} / \mathrm{h}$ led to a relative decline in $\mathrm{HR}$ and $\mathrm{VO}_{2}$, along with more intense growth of BLact.

The power of running at a speed of $16 \mathrm{~km} / \mathrm{h}$ and $\mathrm{HR}$ at a level of 145.3 beats/min, along with a $\mathrm{VO}_{2}$ max at 54.3 $\mathrm{ml} / \mathrm{min} / \mathrm{kg}$, and BLact at $3.7 \mathrm{mmol} / \mathrm{L}$ can be considered the limit of aerobic processes, above which footballers' metabolic processes have a predominance of anaerobic mechanisms for their energy supply - this state is also where lactate begins to accumulate rapidly [29]. Thus, power at running speed on a treadmill of $19 \mathrm{~km} / \mathrm{h}, \mathrm{HR}$ of 177.3 beats $/ \mathrm{min}, \mathrm{VO}_{2}$ levels at $58.8 \mathrm{ml} / \mathrm{min} / \mathrm{kg}$, and a BLact concentration of $4.5 \mathrm{mmol} / \mathrm{L}$ can be considered as an anaerobic threshold.

Statistical analysis of BLact, $\mathrm{HR}, \mathrm{VO}_{2}$, and $\mathrm{V}$ results at the level of AT allowed us to distinguish 5 metabolic modes in football players. For football players with a HR range of 177-187 beats/min, their HR values for the mixed aerobic-anaerobic regime were in the range of 164-174 beats/min, while the values for an aerobic regime were 134-153 beats/min. The pulse is higher than the AT and likely explains the dominance of the lactate mechanism of energy supply. The lactate mechanism for energy supply was characterized by a HR greater than 187 beats/min. For people with HR less than 134.7 beats/min., a restorative aerobic regime of energy supply was established.

\section{Physical activity of football players during a competitive match}

According to the established aerobic/anaerobic modes of energy metabolism, the special physical activity of football players was studied during calendar games with the help of GPSports-system. Indicators of the amount of work performed and the length of the distance travelled, which the players ran in aerobic, aerobicanaerobic, lactic, and alactic modes of energy supply, as well as the average and peak HR, were determined. The results obtained during the football game were compared with the results of $\mathrm{HR} \mathrm{VO}_{2}$ max, Blact, and $\mathrm{V}$ that were obtained on a treadmill in the laboratory (Table 2).

Table 2. Distance length (S, $\mathrm{m})$, gameplay time (\%), and heart rate per game and in different modes of energy metabolism $(\mathrm{n}=29)$

\begin{tabular}{|c|c|c|c|c|c|c|}
\hline \multirow{2}{*}{$\begin{array}{l}\text { Studied } \\
\text { indicators }\end{array}$} & \multirow[b]{2}{*}{ Per game } & \multicolumn{5}{|c|}{ Energy modes } \\
\hline & & Restorative & Aerobic & $\begin{array}{c}\text { Aerobic- } \\
\text { anaerobic }\end{array}$ & Lactic & Alactic \\
\hline $\mathbf{S}, \mathbf{m}$ & $10070.1 \pm 121.4$ & $3268.3 \pm 88.5$ & $4415.6 \pm 93.8$ & $1680.0 \pm 44.3$ & $551.3 \pm 8.4$ & $155.6 \pm 5.7$ \\
\hline $\begin{array}{c}\text { Gameplay time, } \\
\%\end{array}$ & 100 & 32.4 & 43.8 & 16.6 & 5.6 & 1.6 \\
\hline HR, beats $/ \mathrm{min}^{-1}$ & $\begin{array}{c}159.8 \\
{[153 ; 167]}\end{array}$ & $\begin{array}{c}132.9 \\
{[127 ; 136]}\end{array}$ & $\begin{array}{c}142.3 \\
{[129 ; 151]}\end{array}$ & $\begin{array}{c}173.4 \\
{[165 ; 178]}\end{array}$ & $\begin{array}{c}175.4 \\
{[167 ; 182]}\end{array}$ & $\begin{array}{c}177.6 \\
{[168 ; 183]}\end{array}$ \\
\hline
\end{tabular}


The results indicate that the volume of work performed and the length of the distance travelled for the team during the game was $10070.1 \pm 121.4 \mathrm{~m}$. The most significant factor during the game is the changes in aerobic and aerobic-anaerobic energy metabolism. The players spent the majority of game time (43.8\%) in an aerobic mode of energy supply and overcame $4415.6 \pm 93.8 \mathrm{~m}$ on average. Slightly lower (32.4\%) special performance was demonstrated by footballers in the restorative energy regime, as they ran only $3268.3 \pm 88.5 \mathrm{~m}$. In the mixed aerobic-anaerobic regime of energy supply, the physical activity of football players was less than in the aerobic mode at a distance of $1680.0 \pm 44.3 \mathrm{~m}(16.6 \%)$. Low physical activity of football players, in terms of distance travelled, was found to be only $155.6 \pm 5.7 \mathrm{~m} \mathrm{(1.6 \% )}$ in the alactic mode of energy supply and $551.3 \pm 8.4 \mathrm{~m}(5.6 \%)$ in the lactic mode.

The characteristics of special physical activity of football players are known to be the value of HR. Thus, the average HR for the team per game was 159.8 [153; 167] beats/min. The football players achieved the highest volume of running activity when in an aerobic energy mode (43.8\%) with a HR of 142.3 beats/min. The highest HR in the game, 177.6 beats/min, was found in the alactic energy mode. This energy regime provided physical efficiency of approximately $1.6 \%$ of gameplay time. A small share of gameplay time (5.6\%) was spent by footballers at a HR 175.4 beats/min, which corresponded to the lactic acid energy regime. In the mixed aerobic/ anaerobic mode of energy metabolism, HR was 173.4 beats/min, and gameplay time in this mode was $16.6 \%$. Low HR values at 132.9 beats/min were registered in the regenerative aerobic mode of energy supply. In this mode, the players ran a distance of $3268.3 \pm 88.5 \mathrm{~m}$, which was $32.4 \%$ of gameplay time.

Correlation analysis revealed a relationship between the mean HR and $\mathrm{S}$, per game at $\mathrm{r}=0.37(\mathrm{p}=0.031)$. In most cases, high individual HR values coincided with higher rates of special performance of footballers; and conversely, lower levels of running activity corresponded to lower values of average HR.

Thus, studies of playing activity, the amount of running work and the length of distance travelled per game in different energy modes have shown that the high level of special physical performance of elite players is determined by the capacity, power, and efficiency of aerobic and aerobic-anaerobic energy mechanisms.

\section{Discussion}

The results of laboratory and field tests demonstrate high requirements for general and special physical activity of football players in different modes of energy supply. $\mathrm{VO}_{2}$ max, $\mathrm{HR}$, BLact, and AT determinations can be important indicators of physical activity in laboratory tests, but they differ from those obtained in the game. The availability of GPSports-systems has enabled measurements of the individual levels of special physical activity during field conditions. Comparing the results in the laboratory and on-field play allowed us to identify the strengths and weaknesses of general and special physical activity of football players.

We analyzed the results of physical activity and the state of functional systems on a treadmill and during the game in accordance with the various running speeds, which were previously recommended and corresponded to restorative, aerobic, mixed anaerobic/aerobic, lactic, or alactic modes of energy supply $[15,28]$. HR and $\mathrm{VO}_{2}$ max indicators were studied on a treadmill and reflect energy production in aerobic and anaerobic (BLact), as well as in the mixed (AT) modes of energy supply. Moreover, our analysis, which involved the use of telemetry GPSports-systems and "Polar" revealed that in the process of playing activity, special physical activity of football players was supported by a consistent change of various metabolic processes. The analysis of indicators in the laboratory and field conditions revealed that the aerobic energy supply system proved to be the most effective during the game. Its contribution to the game activity of football players was approximately $43.8 \%$. The distance covered by the players in this energy mode is $4415.6 \pm 93.8 \mathrm{~m}$, and HR for the team was $142.3 \mathrm{beats} / \mathrm{min}$. In the laboratory test on a treadmill at a running speed of $16 \mathrm{~km} / \mathrm{h}$, the $\mathrm{VO}_{2}$ max was $54.3 \mathrm{ml} / \mathrm{kg} / \mathrm{min}$ and BLact did not exceed $3.7 \mathrm{mmol} / \mathrm{L}$, which indicated the use of aerobic processes in the body of football players [13]. This is confirmed by the results of the correlation coefficients between $\mathrm{S}$, or distance travelled for players over the course of the game, in the aerobic mode of energy supply, and the $\mathrm{VO}_{2}$ max and $\mathrm{HR}$ indicators obtained on the treadmill (Figure 1). 


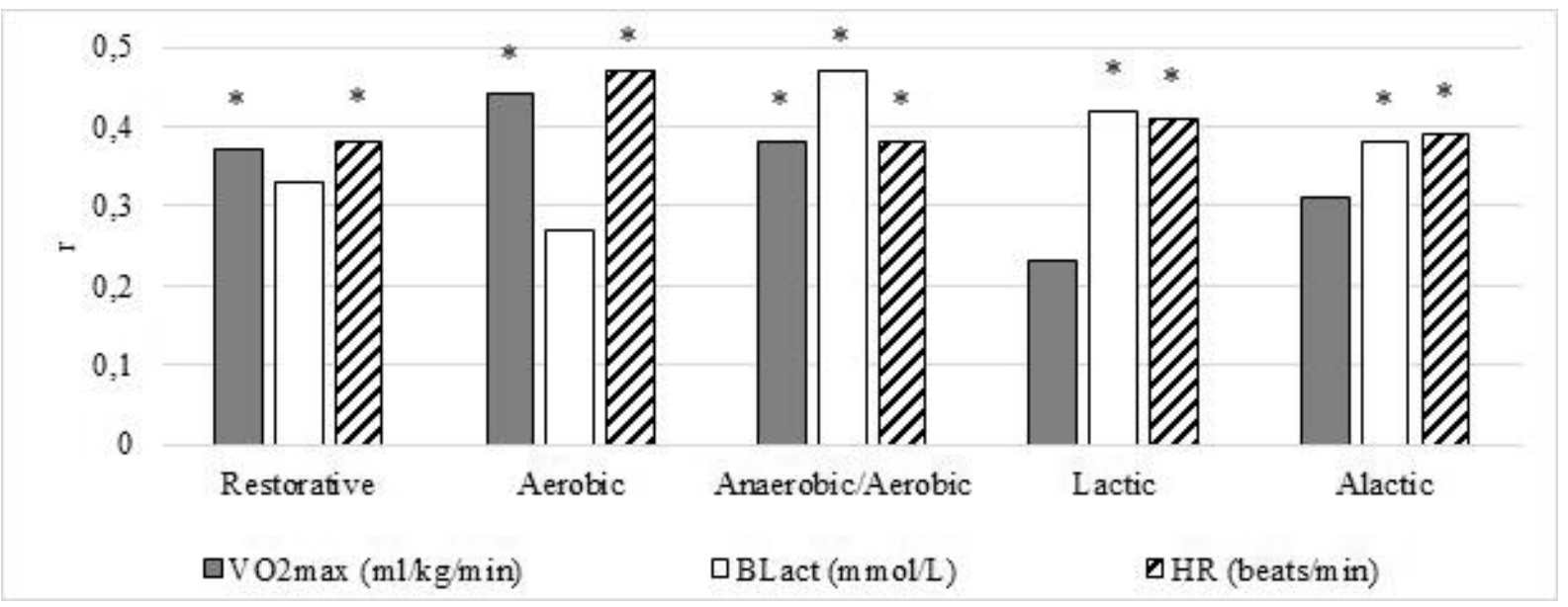

Figure 1. Correlations (r) of the distance travelled during the game in the restorative, aerobic, anaerobic/aerobic, lactic, and alactic modes of energy supply with $\mathrm{VO}_{2} \mathrm{max}$, Blact, and $\mathrm{HR}$ indicators during the treadmill test Notes: * statistically significant correlation coefficients $(\mathrm{p}<0.05)$.

From the above results (Figure 1), the $\mathrm{S}$ correlated with $\mathrm{VO}_{2}$ max during the game in aerobic power mode at a treadmill speed of $16 \mathrm{~km} / \mathrm{h}$ and $\mathrm{r}=0.44(\mathrm{p}=0.021)$, while the content of BLact did not reach a statistically significant correlation $(r=0.27 ; p=0.053)$.

Importantly, HR monitoring best reflects the intensity of physical activity in sports. The question is whether it is enough to control HR for football research; and recent research suggests the game of football is intermittent, stop-start, and HR does not always have time to respond to changes in individual speed, so HR cannot accurately reflect the amount of load $[9,11,14]$. Other investigations suggest HR should be used in studies of energy mechanisms of aerobic character [12]. According to the research results, HR is of the greatest importance for the assessment of aerobic capacity, when as a result of oxidative transformations of fats and carbohydrates, $\mathrm{O}_{2}$ is absorbed, and $\mathrm{CO}_{2}$ and $\mathrm{H}_{2} \mathrm{O}$ are formed $[13,28]$. In our studies, $\mathrm{HR}$ also correlated with $\mathrm{S}$ during an aerobic mode of energy supply throughout the game and was $r=0.47(p=0.028)$. Thus, HR control is an effective method for assessing the metabolic processes of football players [11,23].

During the game, we found using GPSports-systems that football players spent $32.4 \%$ of the game in the restorative aerobic mode of energy supply and ran a distance of $3268.3 \pm 88.5 \mathrm{~m}$. HR in this mode of energy supply was at a level of 132.9 beats/min. In laboratory studies, the restorative mode corresponded to treadmill running speed of $13 \mathrm{~km} / \mathrm{h}$. Under such conditions, the players displays a $\mathrm{VO}_{2} \max$ of $50.3 \mathrm{ml} / \mathrm{kg} / \mathrm{min}$, a HR of $134.7 \mathrm{beats} /$ $\mathrm{min}$, and a BLact concentration of $2.6 \mathrm{mmol} / \mathrm{L}$. The correlation coefficient between $\mathrm{S}$ during the game in the restorative aerobic mode of energy supply with $\mathrm{VO}_{2} \max$, at a treadmill speed of $13 \mathrm{~km} / \mathrm{h}$ was $\mathrm{r}=0.37$ ( $\mathrm{p}=0.047$ ), along with HR $r=0.38(p=0.037)$ (Figure 1). Likewise, the correlation with BLact did not reach a statistically significant relationship ( $\mathrm{r}=0.33 ; \mathrm{p}=0.074)$. From the above results, we can assume that $\mathrm{VO}_{2}$ max at a level of 50 $\mathrm{ml} / \mathrm{kg} / \mathrm{min}$ may be the lower limit of aerobic processes in football players $[4,24]$. The results show that players with a $\mathrm{VO}_{2}$ max below this threshold are unlikely to be able to compete successfully in elite football [26]. This is confirmed by studies showing that in the most successful teams, $\mathrm{VO}_{2}$ max was higher than $67.6 \mathrm{ml} / \mathrm{kg} / \mathrm{min}$. compared to those of less successful teams, who had a $\mathrm{VO}_{2} \max$ of $59.9 \mathrm{ml} / \mathrm{kg} / \mathrm{min}$. [21].

Previous research suggests that indicators of anaerobic/aerobic energy processes in the representatives of elite football clubs in Europe reach $73-74 \%$ of $\mathrm{VO}_{2}$ max, and players are in this mode for more than $20 \%$ of gameplay time $[20,30]$. The results of our research (Table 2) revealed that $S$ per game, in the AT mode for the studied football players, was $1680.0 \pm 44.3 \mathrm{~m}$ on average, along with a HR of 173.4 beats $/ \mathrm{min}$. Moreover, a high level of oxygen consumption $\mathrm{VO}_{2} \max$ at $58.8 \mathrm{ml} / \mathrm{kg} / \mathrm{min}$ and an increase in blood lactate BLact concentrations to $4.5 \mathrm{mmol} / \mathrm{L}$ indicates the inclusion of aerobic-anaerobic processes during special physical activity. The AT indicator for the surveyed football players was $68 \% \mathrm{of}_{\mathrm{VO}_{2}} \max$, while for the leading European clubs, this indicator was at $80 \%$. In our research, aerobic-anaerobic mechanisms of energy supply accounted for only $17 \%$ of playing activities, which is $4-5 \%$ lower than in elite clubs in Europe [7]. These results illustrate the stimulation of aerobic and anaerobic glycolytic processes in the body of football players. Specifically, Figure 1 shows that during the game in aerobic/anaerobic mode of energy supply, $\mathrm{S}$ correlated with $\mathrm{VO}_{2}$ max at a speed of $19 \mathrm{~km} / \mathrm{h}$ on a treadmill at $\mathrm{r}=0.38(\mathrm{p}=0.024)$, and with $\mathrm{HR} \mathrm{r}=0.38(\mathrm{p}=0.036)$. However, a significant correlation was found with the BLact index, which was equal to $r=0.47(p=0.034)$. Thus, the indicators of special physical 
activity of football players, the amount of running work during the game, and the length of distance travelled in a mixed aerobic/anaerobic mode of energy metabolism correlated with the results of functional characteristics of $\mathrm{VO}_{2} \mathrm{max}, \mathrm{HR}$, BLact, and $\mathrm{V}$ on a treadmill at the AT level, demonstrating the high degree of informativeness of these measurements.

Anaerobic lactic and alactic energy regimes proved to be the least effective in providing special physical activity. Footballers were in these modes of energy supply for approximately $5.6 \%$ of gameplay time. The length of the distance the players ran in lactic mode was $551.3 \pm 8.4 \mathrm{~m}$, and in alactic it was $155.6 \pm 5.7 \mathrm{~m}$. The metabolic processes were localized in working muscles and were associated mainly with changes in lactic and alactic anaerobic mechanisms, which was confirmed by the high content of lactate (BLact - 6.7 and $10.9 \mathrm{mmol} / \mathrm{L}$ ) and HR values (173.4-177.6 beats/min). These data indicated the involvement of anaerobic lactic and alactic processes in the body of football players $[13,27]$. The dominance of lactic and alactic mechanisms of energy supply was further indicated by the correlation results (Figure 1). Specifically, during the game in lactic mode of energy supply, $\mathrm{S}$ correlated with the indicator HLact $(\mathrm{r}=0.42 ; \mathrm{p}=0.028)$, and with HR $(\mathrm{r}=0.41 ; \mathrm{p}=0.034)$, which was obtained during treadmill running at a speed of $22 \mathrm{~km} / \mathrm{h}$. Contrarily, there was no correlation of $\mathrm{VO}_{2} \max$ with $S$ in this mode of energy supply $(r=0.23 ; p=0.073)$.

To characterize the relationship of special physical activity with the alactic mode of energy metabolism, we calculated the correlation coefficients of the distance length $(S)$ in the alactic mode of energy supply with $\mathrm{VO}_{2}$ max, HR, and BLact, which were obtained during a laboratory test on a treadmill at a running speed of 25 $\mathrm{km} / \mathrm{h}$. The results (Figure 1) showed that during the game when the players were in alactic mode, S correlated with the content of BLact $(r=0.38 ; p=0.047)$ and with $\mathrm{HR}(\mathrm{r}=0.39 ; \mathrm{p}=0.037)$. Additionally, there was no significant correlation with the $\mathrm{VO}_{2}$ max indicator in the alactic mode of energy supply $(\mathrm{r}=0.31 ; \mathrm{p}=0.064)$. We assume that the sharp acceleration the players use during the game (more than $22 \mathrm{~km} / \mathrm{h}$ ) activates anaerobic processes and creates conditions which influence other metabolic processes. Presumably, first, acceleration in the lactic and alactic modes for football players inhibits the kinetic processes of oxygen uptake and is manifested into the accumulation of lactic acid. Second, during the official game, the athlete cannot achieve high intensity, sprinting work due to high aerobic capacity, or perform sustained exercise with the ball at high speeds $[11,12]$. Third, while oxidizing, fibers are recruited and the lactate concentration does not change. Recruitment of oxidative muscle fibers corresponds to the first ventilation and the aerobic threshold [13,14]. After passing the aerobic threshold, the inclusion of intermediate muscle fibers begins, in which the resynthesis of ATP and CP occurs due to oxidative phosphorylation and anaerobic glycolysis [27]. The beginning of an increase in lactate concentration in the blood indicates the transition from aerobic to anaerobic processes and is defined as AT. Under these conditions, the recruitment of glycolytic muscle fibers begin, which leads to the rapid accumulation of lactate.

Overall, the presented results demonstrate the high reliability of the assessment of physical activity of elite football players using laboratory tests and using GPSports-systems during the game. Thus, understanding the physiological characteristics of general and special physical activity of football players is a fundamental basis of professional football. Therefore, coaching and medical teams should monitor the state of physical activity in different modes of energy supply of football players, analyze and characterize the amount of running work and running speeds obtained by GPS-systems during the game, and ultimately pay attention to $\mathrm{HR}, \mathrm{VO}_{2}$ max, and BLact obtained in laboratory tests on a treadmill $[10,11,28,30]$.

\section{Conclusions}

1. The study of general physical activity in the laboratory using spiroergometric indicators of $\mathrm{VO}_{2}$ max, Blact, and V on a treadmill, as well as $\mathrm{S}, \mathrm{V}$, and HR using telemetric GPS systems during the game, allows for an assessment of functional readiness of football players and energy supply of gaming activities more accurately.

2. The correlation of physical activity with the energy characteristics of anaerobic and aerobic metabolism in elite football players. The correlation coefficient between the length of the distance travelled during the game and the indicators of treadmill running speed at the level of AT was $r=0.54(p=0.032)$, and with the characteristics of spiroergometry $\mathrm{VO}_{2} \max -\mathrm{r}=0.41(\mathrm{p}=0.027)$, with the results of $\mathrm{HR}-\mathrm{r}=0.37$ $(\mathrm{p}=0.047)$, BLact $-\mathrm{r}=0.37(\mathrm{p}=0.034)$.

3. The aerobic energy system proved to be the most effective in providing physical activity during the game. Its contribution to the special physical capacity of football players is $43.8 \%$. Aerobic-anaerobic mechanisms of energy supply provide $17 \%$ of gaming activity. Anaerobic lactic (5.6\%) and alactic $(1.6 \%)$ modes of energy supply were least effective during gaming activity. 
4. The specific indicators $\mathrm{HR}, \mathrm{VO}_{2} \max$, Blact, running speed on a treadmill, and distance travelled at different modes of energy supply during the game can be an informative criterion for determining the functional state of the body in football players and other playing sports.

\section{References:}

1. Bompa T. Total training for young champions. Champaign: Human Kinetics; 2000.

2. Wilmore JH, Costill D, Kenney WL. Physiology of sport and exercise. 4th ed. Champaign: Human Kinetics; 2009.

3. Platonov VM. [Motor qualities and physical training of athletes]. Kyiv: Olympic Literature; 2017 (in Ukrainian).

4. Shamardin VN, Vinogradov VE, Diachenko AY. [Physical training of highly qualified football players]. Kiyv: NVF; 2017 (in Ukrainian).

5. Papp K. [High intensity soccer play]. Budapest: Sport Generation; 2019 (in Hungarian).

6. Lyzohub VS, Shpaniuk VV. [An innovative approach to determining and evaluating the special training of highly qualified players]. Science and Education. 2017; 8: 15-22 (in Ukrainian).

7. Lyzohub VS, Shpaniuk VV, Pustovalov VO, Kozhemiako TV. [Relationship between physical performance and bioenergetic mechanisms of ensuring the game activity of football players]. Visnyk of Cherkasy University. Biological Sciences. 2020; 2: 66-76 (in Ukrainian). https://doi.org/10.31651/2076-5835-2018-1-2020-2-66-75

8. Nikolaenko VV. [Rational system of long-term training of football players to achieve the highest sportsmanship]. Kyiv: Summit Book; 2014 (in Ukrainian).

9. Boguszewski D, Ochal A, Adamczyk J, Jasiński P, Szymańska A, Obszyńska-Litwiniec A, et al. Physical activity of physiotherapy students at the Medical University of Warsaw. Health Prob Civil. 2021; 15(1): 48-53. https://doi.org/10.5114/hpc.2020.97678

10. Stolen T, Chamari K, Castagna C, Wisloff U. Physiology of football: an update. Sports Med. 2005; 35: 501-536. https://doi.org/10.2165/00007256-200535060-00004

11. Owen AL, Dellal A. Football conditioning a modern scientific approach: periodization - seasonal training small sided games. Celbridge: SoccerTutor.com Ltd; 2016.

12. Seluyanov VM, Sarsania SK, Zavorova VA. [Football: problems of physical and technical training]. Moscow: Intellect; 2012 (in Russian).

13. Volkov NI, Nessen EN, Osipenko AA. [Biochemistry of muscular activity]. Kyiv: Olympic Literature; 2000 (in Ukrainian).

14. Mishchenko VS, Lysenko EN, Vinogradov VE. [Reactive properties of the cardiorespiratory system as a reflection of adaptation to intense physical training in sports]. Kyiv: The Scientific World; 2007 (in Ukrainian).

15. Bradley PS, Sheldon W, Wooster B, Olsen P, Boanas P, Krustrup P. High-intensity running in English FA Premier League, soccer matches. Journal of Sports Sciences. 2009; 27(2): 159-168. https://doi.org/10.1080/02640410802512775

16. Bloomfield J, Polman RCJ, O'Donoghue PG. Physical demands of different positions in FA Premier League football. Journal of Sports Science \& Medicine. 2007; 6(1): 63-70.

17. Dellal A, Diniz da Silva C, Hill-Haas S, Wong DP, Natali AJ, De Lima J, et al. Heart rate monitoring in football: interest and limits during competitive match play and training, practical application. The Journal of Strength and Conditioning Research. 2012; 26(10): 2890-2906. https://doi.org/10.1519/JSC.0b013e3182429ac7

18. Di Mascio M, Bradley PS. Evaluation of the most intense high-intensity running period in English FA premier league football matches. The Journal of Strength and Conditioning Research. 2013; 27(4): 909-915. https://doi.org/10.1519/JSC.0b013e31825ff099

19. Miyagi O, Ohashi J, Kitagawa K. Motion characteristics of an elite football player during a game. Journal of Sports Science. 1999; 17(10): 816-827.

20. Aziz AR, Chia MYH, Teh KC. Measured maximal oxygen uptake in a multi-stage shuttle test and treadmill-run test in trained athletes. The Journal of Sports Medicine and Physical Fitness. 2005; 45: 306-314.

21. Carey D, Drake M, Pliego G, Raymond R. Do hockey players need aerobic fitness? Relation between V02max and fatigue during high-intensity intermittent ice skating. Journal of Strength and Conditioning Research. 2007; 21(3): 963-966. https://doi.org/10.1519/R-18881.1

22. Bosquet L, Leger L, Legros P. Methods to determine aerobic endurance. Sports Medicine. 2002; 32(1): 675700. https://doi.org/10.2165/00007256-200232110-00002

23. Gamble P. Strength and conditioning for team sports: sports-specific physical preparation for high performance. 2nd ed. London: Routledge; 2013. 
24. Da Silva JF, Dittrich N, Guglielmo L. Aerobic evaluation in football. Rev Bras Cineantropom Desempenho Hum. 2011; 13(5): 384-391. https://doi.org/10.5007/1980-0037.2011v13n5p384

25. Wasserman K,Hansen E,Sue DY.Exercisetestingandinterpretation.Philadelphia:LippicottWilliams\&Wilkins; 2005; p. 228-237.

26. Reilly T, Bangsbo J, Franks A. Anthropometric and physiological predispositions for elite football. J Sports Sci. 2000; 18(9): 669-683. https://doi.org/10.1080/02640410050120050

27. Shephard RJ. Tests of maximum oxygen intake, a critical review. Sports Med. 1984; 1: 99-124. https://doi.org/10.2165/00007256-198401020-00002

28. Karpman VL, Belotserkovsky ZB, Gudkov IA. [Testing in sports medicine]. Moscow: FiS; 2008 (in Russian).

29. Glantz SA. Primer of biostatistics. New York: McGraw-Hill; 2012.

30. Michalčíková T, Vorlíček M, Pechová J, Jakubec L, Frömel K, Neumannová K. Physical activity of physiotherapy students and the role of device-based monitoring in their future clinical practice: a cohort study. Health Prob Civil. 2020; 14(2): 107-117. https://doi.org/10.5114/hpc.2020.94271 